NBER WORKING PAPER SERIES

\title{
EXECUTIVE COMPENSATION AS AN AGENCY PROBLEM
}

\author{
Lucian Arye Bebchuk \\ Jesse M. Fried \\ Working Paper 9813 \\ http://www.nber.org/papers/w9813 \\ NATIONAL BUREAU OF ECONOMIC RESEARCH \\ 1050 Massachusetts Avenue \\ Cambridge, MA 02138 \\ July 2003
}

We are grateful to Bradford Delong, Andrei Shleifer, Timothy Taylor, and Michael Waldman for many valuable suggestions. For financial support, we would like to thank the John M. Olin Center for Law, Economics, and Business (Bebchuk) and the Boalt Hall Fund and U.C. Berkeley Committee on Research (Fried). The views expressed herein are those of the authors and not necessarily those of the National Bureau of Economic Research

(C)2003 by Lucian Arye Bebchuk and Jesse M. Fried. All rights reserved. Short sections of text not to exceed two paragraphs, may be quoted without explicit permission provided that full credit including (C) notice, is given to the source. 
Executive Compensation as an Agency Problem

Lucian Arye Bebchuk and Jesse M. Fried

NBER Working Paper No. 9813

July 2003

JEL No. D23, G32, G34, G38, J33, J44, K22, M14

\begin{abstract}
$\underline{\text { ABSTRACT }}$
This paper provides an overview of the main theoretical elements and empirical underpinnings of a "managerial power" approach to executive compensation. Under this approach, the design of executive compensation is viewed not only as an instrument for addressing the agency problem between managers and shareholders but also as part of the agency problem itself. Boards of publicly traded companies with dispersed ownership, we argue, cannot be expected to bargain at arm's length with managers. As a result, managers wield substantial influence over their own pay arrangements, and they have an interest in reducing the saliency of the amount of their pay and the extent to which that pay is de-coupled from managers' performance. We show that the managerial power approach can explain many features of the executive compensation landscape, including ones that many researchers have long viewed as puzzling. Among other things, we discuss option plan design, stealth compensation, executive loans, payments to departing executives, retirement benefits, the use of compensation consultants, and the observed relationship between CEO power and pay. We also explain how managerial influence might lead to substantially inefficient arrangements that produce weak or even perverse incentives.
\end{abstract}

Lucian Arye Bebchuk

John M. Olin Center

for Law, Economics, and Business

Harvard Law School

1557 Massachusetts Avenue

Cambridge, MA 02138

and NBER

bebchuk@law.harvard.edu
Jesse M. Fried

Boalt Hall School of Law

University of California at Berkeley

Berkeley, CA 94720

friedj@law.berkeley.edu 
Executive compensation has long attracted a great deal of attention from financial economists. Indeed, the increase in academic papers on the subject of CEO compensation during the 1990's seems to have outpaced even the remarkable increase in CEO pay itself during this period (Murphy (1999)). Much research has focused on how executive compensation schemes can help alleviate the agency problem in publicly traded companies. To adequately understand the landscape of executive compensation, however, it is necessary to recognize that the design of compensation schemes is also partly a product of this same agency problem.

\section{Alternative Approaches to EXeCutive COMPENSATION}

Our focus in this paper is on publicly traded companies without a controlling shareholder. When ownership and management are separated in this way, managers might have substantial power. This recognition goes back, of course, to Berle and Means (1933) who observed that "[D]irectors, while in office, have almost complete discretion in management" (p. 139). Since Jensen and Meckling (1976), the problem of managerial power and discretion has been analyzed in modern finance as an "agency problem."

Managers may use their discretion to benefit their private interests in a variety of ways (Shleifer and Vishny (1997)). For example, managers may engage in empire building (Jensen, (1974), Williamson (1964)). They may, as Jensen (1986) suggests, fail to distribute excess cash when the firm does not have profitable investment opportunities. Managers also may entrench themselves in their positions, making it difficult to oust them when they perform poorly (Shleifer and Vishny (1989)). Any discussion of executive compensation must proceed against the background of the fundamental agency problem afflicting management decision-making. There are two different views, however, on how the agency problem and executive compensation might be linked.

Among financial economists, the dominant approach to the study of executive compensation views these pay arrangements as a (partial) remedy to the agency problem. Under this approach, which we label "the optimal contracting approach," boards are assumed to design compensation schemes to provide managers with efficient incentives to maximize shareholder value. Financial economists have done substantial work within this optimal contracting model in an effort to understand executive compensation practices. Recent surveys of this work include Murphy (1999) and Core, Guay, and Larcker (2001). To researchers working within the optimal contracting model, the main flaw with existing practices seems to be that, due to political limitations on how generously 
executives can be treated, compensation schemes are not sufficiently highpowered (Jensen and Murphy (1990)).

Another approach to studying executive compensation focuses on a different link between the agency problem and executive compensation. Under this approach, which we label the "managerial power approach," executive compensation is viewed not only as a potential instrument for addressing agency problems - but also as part of the agency problem itself. As a number of researchers have recognized, some features of pay arrangements seem to reflect managerial rent seeking rather than the provision of efficient incentives (e.g., Blanchard, Lopez-de-Silanes, and Shleifer, (1994), Yermack (1997), and Bertrand and Mullainathan (2001)). We seek to develop a full account of how managerial influence shapes the executive compensation landscape in a forthcoming book (Bebchuk and Fried (2004)) that builds substantially on a long article written jointly with David Walker (Bebchuk, Fried, and Walker (2002)).

Drawing on this work, we argue below that managerial power and rent extraction are likely to have an important influence on the design of compensation arrangements. Indeed, the managerial power approach can shed light on many significant features of the executive compensation landscape that have long been seen as puzzling by researchers working within the optimal contracting model. We also explain that managerial influence on pay might impose substantial costs on shareholders - beyond the amount of excess pay executives receive - by diluting and distorting managers' incentives and thereby hurting corporate performance.

Although the managerial power approach is conceptually quite different from the optimal contracting approach, the former is not proposed as a complete replacement for the latter. Compensation arrangements might be shaped both by market forces, which push toward value-maximizing arrangements, and by managerial influence, which pushes toward departures from optimal arrangements in directions favorable to managers. The managerial power approach simply claims that these departures from value-maximizing arrangements are substantial and that compensation practices thus cannot be adequately explained by optimal contracting alone.

\section{THE LimitATIONS OF OPTIMAL CONTRACTING}

The optimal contracting view recognizes that managers suffer from an agency problem and do not automatically seek to maximize shareholder value. Thus, providing managers with adequate incentives is important. Under the optimal contracting view, the board, working in shareholders' interest, attempts 
to cost-effectively provide such incentives to managers through their compensation packages.

Optimal compensation contracts could result either from effective arm's length bargaining between the board and the executives, or from market constraints that induce these parties to adopt such contracts even in the absence of arm's length bargaining. However, neither of these forces can be expected to constrain effectively departures from arm's length outcomes. ${ }^{1}$

Just as there is no reason to presume that managers automatically seek to maximize shareholder value, there is no reason to expect a priori that directors will either. Indeed, an analysis of directors' incentives and circumstances suggests that directors' behavior is also subject to an agency problem. The director agency problem undermines the board's ability to effectively address the agency problems in the relationship between managers and shareholders.

Directors will generally wish to be re-appointed to the board. Average director compensation in the 200 largest US corporations in 2001 was $\$ 152,626$ (Pearl Meyers and Partners (2002)). In the notorious Enron case, the directors were each paid $\$ 380,000$ in 2001 (Abelson (2001)). Besides an attractive salary, a directorship is also likely to provide prestige and valuable business and social connections. Thus, because of the important role CEO's play in re-nominating directors to the board, directors typically have an incentive to favor the CEO.

To be sure, in a world in which shareholders selected individual directors, directors might have an incentive to develop reputations as shareholder-serving. However, board elections are by slate, dissidents putting forward a competing slate confront substantial impediments, and such challenges are therefore exceedingly rare (Bebchuk and Kahan (1990)). Typically, the director slate proposed by management is the only one offered.

The key to a board position is thus being on the company's slate. Because the CEO's influence over the board gives her significant influence over the nomination process, directors have an incentive to "go along" with the CEO's pay arrangement, a matter dear to the CEO's heart, at least as long as the compensation package remains within the range of what can be defended and justified. In addition, because being on the company's slate is the key to being appointed, developing a reputation for haggling with the CEO over her compensation would hurt rather than help a director's chances of being invited to join other companies' boards. Yet another reason to favor the CEO is that the CEO can affect directors' compensation and perks.

1 Shareholders could try to challenge undesirable pay arrangements in court. However, corporate law rules effectively prevent courts from reviewing compensation decisions. (Bebchuk, Fried, and Walker (2002), at 779-781). 
Directors typically have only nominal equity interests in the firm (Baker, Jensen, and Murphy (1988), Core, Holthausen, and Larcker (1999)). Even if a director did not place much value on a board seat, he would still have little personal motivation to fight the CEO, or other directors who wish to please the CEO, on compensation matters. And, in any event, directors usually lack easy access to the independent information and advice on compensation practices necessary to effectively challenge the CEO's pay.

Finally, market forces are not sufficiently strong and fine-tuned to assure optimal contracting outcomes. Markets -- including the market for control, the market for capital, and the labor market for executives -- impose some constraints on what directors will agree to and what managers will ask them to approve. An analysis of these markets, however, indicates that the constraints they impose are far from tight and permit substantial deviations from optimal contracting (Bebchuk, Fried, and Walker (2002)).

Consider, for example, the market for corporate control - the threat of a takeover. Firms frequently have substantial defenses against takeovers. For example, a majority of companies have a staggered board, which prevents a hostile acquirer from gaining control for at least a year and often enables incumbent managers to block hostile bids that are attractive to shareholders (Bebchuk, Coates, and Subramanian (2002)). To overcome incumbent opposition, a hostile bidder must be prepared to pay a substantial premium; during the second half of the 1990's, the average premium in hostile acquisitions was $40 \%$ (Bebchuk, Coates, and Subramanian (2002)). The market for corporate control thus leaves managers with considerable slack and ability to extract private benefits. The disciplinary force of the market for corporate control is further weakened by the prevalence of golden parachute provisions, as well as by the acquisition-related benefits that target managers often are given to facilitate an acquisition (Bebchuk and Fried (2004)). To be sure, the market for control might impose some costs on managers who are especially aggressive in extracting rents; we later note evidence that CEO's of firms with stronger takeover protection get pay packages that are both larger and less performance sensitive. The important point is that the market for corporate control fails to impose tight constraints on executive compensation.

Some responses to our earlier work assumed that our analysis of the absence of arm's length bargaining assumed that it does not apply to cases in which boards negotiate pay with a CEO candidate from outside the firm (see, e.g., Murphy (2002)). However, while such negotiations might be closer to the arm's length model than negotiations with an incumbent CEO, they still fall quite short of this benchmark. Among other things, directors negotiating with an outside CEO candidate know that after the candidate becomes CEO she will have 
influence over their re-nomination to the board and over their compensation and perks. The directors will also wish to have a good personal and working relationship with the person who is expected to become the firm's leader and a fellow board member. And while agreeing to a pay package that favors the new CEO imposes little financial cost on the directors, any breakdown in the hiring negotiations, which might embarrass the directors and in any event force them to re-open the CEO selection process, would be personally costly to them. Finally, directors' limited time forces them to rely on information shaped and presented by the company's human resources staff and compensation consultants, all of whom have incentives to please the incoming CEO.

\section{THE MANAgERIAL POWER APPROACH}

The very reasons for questioning the ability of optimal contracting to adequately explain compensation practices suggest that executives have substantial influence over their own pay. These reasons also suggest that the greater managers' power, the greater their ability to extract rents. There are limits to what directors will accept and what markets will permit, but these constraints do not prevent managers from obtaining arrangements more favorable than those obtainable under arm's length bargaining.

One important building block of the managerial power approach is that of "outrage" costs and constraints. The tightness of the constraints managers and directors confront depends, in part, on how much "outrage" a proposed arrangement is expected to generate among relevant outsiders. Outrage might cause embarrassment or reputational harm to directors and managers, and it might reduce shareholders' willingness to support incumbents in proxy contests or takeover bids. The more outrage a compensation arrangement is expected to generate, the more reluctant directors will be to approve the arrangement, and the more hesitant managers will be to propose it in the first instance. Thus, whether a compensation arrangement that is favorable to executives but suboptimal for shareholders is adopted will depend on how it is perceived by outsiders.

There is evidence that the design of compensation arrangements is indeed influenced by how outsiders perceive them. Johnson, Porter, and Shackell (1997) find that CEO's of firms receiving negative media coverage of their compensation arrangements during 1992-94 received relatively small pay increases during subsequent years and had their compensation's pay-performance sensitivity increased. Thomas and Martin (1999) find that, during the 1990's, CEO's of firms that were the target of shareholder resolutions criticizing executive pay had their annual compensation reduced over the following two years by $\$ 2.7$ million. 
The potential significance of outsiders' perception of a CEO's compensation and of outrage costs explains the importance of yet another building block of the managerial power approach - "camouflage." To avoid or minimize outrage resulting from outsiders' recognizing the presence of rent extraction, managers have a substantial incentive to obscure and to try to legitimize-or, more generally, to camouflage-their extraction of rents. The strong desire to camouflage might lead to the adoption of inefficient compensation structures that hurt managerial incentives and firm performance. This concept of camouflage turns out to be quite useful in explaining many otherwise puzzling features of the executive compensation landscape.

The importance of how compensation arrangements are perceived means that, in the executive compensation area, the transparency of disclosure matters. Financial economists often focus on the role of disclosure in getting information incorporated into market pricing. It is widely believed that information can become reflected in stock prices as long as it is known and fully understood by a limited number of market professionals. In the executive compensation context, however, the ability of plan designers to choose arrangements that favor managers depends on how these arrangements are perceived by a much wider group of outsiders. As a result, the transparency and salience of disclosure can have a significant effect on CEO compensation.

Murphy (2002) and Hall and Murphy (2003) argue that our approach cannot explain increases in managerial pay during the 1990's. In their view, CEO power declined during this period. Given the strengthening of takeover defenses during the 90's, however, it is unclear whether CEO power diminished during this period. In any event, in our view, executive pay increases during the 1990's resulted not from changes in managerial power but rather from other factors, none of which is inconsistent with our approach.

First, seeking to make pay more sensitive to performance, regulators and shareholders encouraged the use of equity-based compensation. Taking advantage of this enthusiasm, executives used their influence to obtain substantial option pay without giving up corresponding amounts of their cash compensation; furthermore, the options they received did not link pay tightly to the managers' own performance but rather enabled managers to reap windfalls from that part of the stock price increase due solely to market and sector trends beyond their control; as a result, managers were able to capture much larger gains than more cost-effective and efficient plans would have provided. Second, because executive compensation has historically been correlated with market capitalization, the rising stock markets of the 1990s, which carried along with them even many poorly performing companies, provided a convenient justification at most firms for substantial pay increases. Third, market booms 
weaken outrage constraints; exuberant shareholders are less likely to scrutinize and resent generous pay arrangements, in the same way that the recent market declines has made shareholders more prone to do so.

\section{POWER AND CAMOuflage AT WORK}

We illustrate below the potential value of the managerial power approach by discussing four patterns and practices that can at least partly be explained by power and camouflage: the relationship between power and pay; the use of compensation consultants; executive loans; and golden good-bye payments to departing executives.

\section{A. Power-Pay Relationships}

The managerial power approach predicts that pay will be higher and/or less sensitive to performance in firms in which managers have relatively more power. Other things being equal, managers would tend to have more power when: (i) the board is relatively weak or ineffectual; (ii) there is no large outside shareholder; (iii) there are fewer institutional shareholders; or (iv) the managers are protected by antitakeover arrangements. There is evidence indicating that each of these factors affects pay arrangements in the way predicted by the managerial power approach.

Executive compensation is higher when the board is relatively weak or ineffectual vis-à-vis the CEO. Core, Holthausen, and Larcker (1999), examining 205 large public firms, find that CEO compensation is higher under the following conditions: when the board is large, making it more difficult for directors to organize in opposition to the CEO; when more of the outside directors have been appointed by the CEO, which could cause them to feel gratitude or obligation to the CEO; and when outside directors serve on three or more boards, and thus more likely to be distracted. Also, CEO pay is $20-40 \%$ higher if the CEO is the chairman of the board ((Cyert, Kang, and Kumar (2002), Core, Holthausen, and Larcker (1999)). Finally, CEO pay is negatively related to the share ownership of the board's compensation committee; doubling the compensation committee ownership reduces non-salary compensation by $4-5 \%$ (Cyert, Kang, and Kumar (2002)).

The presence of a large outside shareholder is likely to result in closer monitoring (Shleifer and Vishny (1986)) and thus can be expected to reduce managers' influence over their compensation. Consistent with this observation, Cyert, Kang, and Kumar (2002) find a negative relationship between the equity ownership of the largest shareholder and the amount of CEO compensation; 
doubling the percentage ownership of the outside shareholder reduces non-salary compensation by $12-14 \%$. Bertrand and Mullainathan (2000) find that CEO's in firms that lack a 5 percent (or larger) external shareholder tend to receive more "luck-based" pay - pay associated with profit increases that are entirely generated by external factors (e.g., changes in oil prices and exchange rates) rather than by managers' efforts. They also find that, in firms that lack large external shareholders, the cash compensation of CEO's is reduced less when their options-based compensation is increased. Relatedly, in an examination of S\&P 500 firms during the period 1992-97, Benz, Kucher, and Stutzer (2001) find that a higher concentration of shareholders significantly reduces the number of granted options.

A larger concentration of institutional shareholders might result in greater monitoring and scrutiny of the CEO and the board. Examining CEO pay in almost 2000 firms during the period 1991-1997, Hartzell and Starks (2002) find that more concentrated institutional ownership leads to lower executive compensation. They also find that a larger institutional presence results in more performancesensitive compensation. Examining CEO compensation in the 200 largest companies during 1990-1994, David, Kochar and Levitas (1998) find that the effect of institutional shareholders on CEO pay depends on the types of relationships they have with the firm. They divide institutional shareholders into: (1) ones having no other business relationship with the firm and thus concerned only with the firm's share value ("pressure-resistant" institutions); and (2) ones having other business relationships with the firm (e.g., managing a pension fund) and thus vulnerable to management pressure ("pressure-sensitive" institutions). As the managerial power approach predicts, CEO pay is negatively correlated with the presence of pressure-resistant institutional investors and positively correlated with the presence of pressure-sensitive ones.

The adoption of antitakeover provisions makes CEO's less vulnerable to a hostile takeover. Borokhovich, Brunarski and Parrino (1997), examining 129 firms that adopted anti-takeover provisions (such as a supermajority rule) during the period 1979-1987, find that CEO's of firms adopting such provisions enjoy abovemarket compensation before adoption of the anti-takeover provisions and that adoption of these provisions increases their excess compensation significantly. This pattern is not readily explainable by optimal contracting; indeed, if managers' jobs are more secure, shareholders should be able to pay managers a lower risk premium (Agrawal and Knoeber (1998)). In another study, Cheng, Nagar, and Rajan (2001) find that CEO's of Forbes 500 firms that became protected by new state anti-takeover legislation enacted during the period 19841991 reduced their holdings of shares by an average of 15\%, apparently because the shares were not as necessary for maintaining control. Optimal contracting 
might predict that a CEO protected by anti-takeover legislation would be required to buy more shares to restore her incentive to increase shareholder value.

\section{B. Compensation Consultants}

U.S. public companies typically employ outside consultants to provide advice about executive compensation (Bizjack, Lemmon, and Naveen (2000)). The use of consultants can be explained within the optimal-contracting framework on grounds that they supply useful information and contribute expertise on the design of compensation packages. But although compensation consultants can sometimes play a useful role, they also can play a role in camouflaging rents. The incentives of compensation consultants - and the evidence regarding their usesuggest that these consultants are often used to justify executive pay rather than to optimize it.

Compensation consultants have strong incentives to use their discretion to help the CEO. The consultant is usually hired by the firm's human resources department, which is subordinate to the CEO. Providing advice that hurts the CEO's pocketbook is hardly a way to enhance the consultant's chances of being hired in the future by this firm or, indeed, by any other firm. Moreover, consulting firms often have other, larger assignments with the hiring company, which further increases their incentive to please the CEO (Crystal (1991)).

Pay consultants favor the CEO by providing the types of compensation data that are most useful for justifying a high level of pay. For example, when firms do well, consultants recommend increasing compensation, arguing that pay should reflect performance and should be higher than the average in the industry -- and certainly higher than that of CEO's who are doing poorly. In contrast, when firms do poorly, the consultants focus not on performance data but rather on peer group pay to argue that CEO compensation should be higher to reflect prevailing industry levels (Gillan (2001)).

After the compensation consultant has collected and presented the "relevant" comparative data, the board generally sets pay equal to or higher than the median CEO pay in the comparison group. Reviewing the reports of compensation committees in 100 large companies, Bizjack, Lemmon, and Naveen (2000) find that a large majority of them used peer groups in determining pay and set compensation at or above the fiftieth percentile of the peer group. The combination of helpful compensation consultants and sympathetic boards is in part responsible for the widely recognized "ratcheting up" of executive salaries (Murphy (1999), p. 2525). 
After the board compensation approves the compensation package, firms use compensation consultants and their reports to justify executive compensation to shareholders. Examining S\&P 500 companies during the period 1987-1992, Wade, Porac and Pollack (1997) find that companies that pay their CEO's larger base salaries, and firms with more concentrated and active outside ownership, are more likely to cite the use of surveys and consultants in justifying executive pay in their proxy reports to shareholders. This study also finds that, when accounting returns are high, firms emphasize the accounting returns and downplay market returns.

\section{Stealth Compensation}

As we document in Bebchuk and Fried (2003), firms use pay practices that make less transparent the total amount of executive compensation and the extent to which managers' compensation is de-coupled from their own performance. Among the arrangements used by firms that camouflage the amount and the performance-insensitivity of the compensation paid executives are pension plans, deferred compensation, and post-retirement perks and consulting contracts.

Most of the pension and deferred compensation benefits given to executives do not enjoy the large tax subsidy enjoyed by the standard retirement arrangements provided to other employees. In the case of executives, however, such arrangements largely shift tax liability from the executive to the firm in ways that can increase the joint tax liability of the two parties. The efficiency grounds for providing compensation through in-kind retirement perks and guaranteed post-retirement consulting fees are also far from clear. All of these arrangements, however, make pay less salient.

Among other things, under existing disclosure rules, firms do not have to place a dollar value on - and include in the firm's publicly filed compensation tables -- compensation provided to executives after they retire from the firm. Although the existence of executives' retirement arrangements must be noted in certain places in the firm's public filings, this disclosure is less salient because outsiders focus on the dollar amounts reported in the compensation tables. Indeed, the compensation table amounts are used by the ExecuComp database, which is the basis for much of the empirical work on executive compensation.

Another practice with camouflage benefits is the use of executive loans. While the Sarbanes-Oxley Act of 2002 now prohibits such loans, prior to the Act's adoption more than 75 percent of the 1,500 largest U.S. firms lent money to executives (King (2002)). It is not readily apparent that having firms (rather than banks) lend to executives - or that providing compensation in the form of 
favorable interest rates - is efficient. But loans are useful for reducing the saliency of managers' compensation.

To begin with, the implicit compensation provided by below-market rate loans often does not appear in the compensation tables. Firms are required by SEC rules to disclose in the tables, under the category of "other annual compensation," the difference between the interest actually paid on executive loans and "the market rate." However, the SEC has not defined "market rate," and firms have interpreted the term in a manner that enabled them to exclude the value of large interest subsidies from the compensation tables. For example, WorldCom did not report in its compensation tables any income to CEO Bernard Ebbers from the over $\$ 400$ million of loans he received at an interest rate of 2.15 percent. Worldcom later explained that 2.15 percent was the "market rate" at which WorldCom was borrowing under one of its credit facilities. However, 2.15 percent was far below the more than 5 percent rate that Ebbers would have paid at that time in the market to borrow funds. With the existence and terms of the loans (but without any estimate of the value of the conferred benefits) buried in the disclosures of related-party transactions in the firm's public filings and not reflected in WorldCom's compensation tables, Ebbers' large benefits from the loan received no media attention and no outside scrutiny until WorldCom became involved in an accounting scandal.

Another manner in which loans can provide camouflage is through the practice of loan forgiveness. Firms that provided executives with a loan to buy a large amount of stock often do not demand repayment if the stock value falls below the amount due on the loan. As a result, the arrangement is similar to (but usually more tax-inefficient than) granting the executive an option to buy shares at a price equal to the amount owed on the loan. However, firms must include the value of option grants in the compensation tables for the year the grant is made. In contrast, when granting a loan that will likely be forgiven if the stock price drops, firms do not need to include the option value of the arrangement in the compensation tables. If the stock price falls, the loan will often be forgiven at the time the executive leaves the company, when any resulting outrage is likely to have little impact on the executive personally. For example, George Shaheen, the Webvan CEO who resigned shortly before Webvan went bankrupt, had a $\$ 6.7$ million loan forgiven in exchange for $\$ 150,000$ of Webvan stock (Lublin (2002)).

\section{Golden Goodbyes}

A "golden goodbye" refers to the practice of the board giving a departing CEO payments and benefits that are gratuitous -- not required under the terms of 
the CEO's compensation contract. Such golden goodbyes are common even when CEO's perform so poorly that their boards feel compelled to replace them.

Compensation contracts usually provide executives with generous severance arrangements even when they depart following very dismal performance. Such "soft landing" provisions provide executives with insurance against being fired due to poor performance. It is far from clear that these arrangements reflect optimal contracting; after all, such provisions reduce the difference in managerial payoffs between good and poor performance that firms spend so much to create. Our focus, however, is on payments that go beyond the severance arrangements that are contractually specified.

For example, when Mattel CEO Jill Barad resigned under fire, the board forgave a $\$ 4.2$ million loan, gave her an additional $\$ 3.3$ million in cash to cover the taxes for forgiveness of another loan, and allowed her unvested options to automatically vest and remain exercisable until the end of their original terms. These gratuitous benefits were in addition to the considerable benefits that she received under her employment agreement, which included a termination payment of $\$ 26.4$ million and a stream of retirement benefits exceeding $\$ 700,000$ per year.

It is hard to reconcile such gratuitous payments with the arm's length, optimal contracting model. The board has the authority to fire the CEO and pay the CEO her contractual severance benefits. Thus, there is no need to "bribe" a poorly performing CEO to step down. In addition, the signal sent by the golden goodbye will, if anything, only weaken the incentive of the next CEO to perform.

The making of such gratuitous payments, however, is quite consistent with the existence of managerial influence over the board. Because of their relationship with the CEO, some directors might be unwilling to replace the existing CEO unless she is very generously treated. Other directors might be willing to replace the CEO in any event but prefer to accompany the move with a golden goodbye in order to confer a favor on the CEO, to alleviate the discomfort they otherwise would feel in forcing out the CEO, or to make the difficult separation process more pleasant and less contentious. In all of these cases, directors' willingness to make gratuitous payments to the (poorly performing) CEO results from the CEO's relationship with, and influence over, the directors.

It is important to note that, taking managerial power as given, providing golden goodbyes to fired CEO's might be beneficial to shareholders in some instances. If many directors are loyal to the CEO, such a golden goodbye might be necessary to assemble a board majority in favor of replacing him. In such a case, the golden goodbye would help shareholders when the CEO's departure is more beneficial to shareholders than the cost to them of the golden goodbye payment. For our purposes, however, what is important is that these gratuitous payments, 
whether they are beneficial to shareholders or not, reflect the existence and significance of managerial influence.

\section{Suboptimal Pay Structures}

\section{A. Pay Without Performance}

Optimal contracting arrangements might involve very large amounts of compensation for executives, provided that such compensation is designed to provide managers with powerful incentives to increase shareholder value (Jensen and Murphy (1990)). The problem with current arrangements, however, is that the generous compensation provided executives is linked only weakly to managerial performance. This pay-performance disconnect is puzzling from an optimal contracting view.

The substantial part of compensation that is not equity-based has long been criticized as weakly linked to managerial performance. During the 1990s, there was no significant correlation between a CEO's salary and bonus and her firm's industry-adjusted performance (Murphy (1999)). Similarly, cash compensation increases when firm profits rise for reasons that clearly have nothing to do with managers' efforts (Blanchard, Lopez-de-Silanes, and Shleifer (1994), Bertrand and Mullainathan (2001)). Furthermore, managers receive substantial non-equity compensation through arrangements that have received little attention from financial economists - such as pensions, deferred benefits, and favorable loans and this compensation is also relatively insensitive to managers' own performance.

In light of the historically weak link between non-equity compensation and managerial performance, shareholders and regulators wishing to strengthen the connection between pay and performance have increasingly looked to, and encouraged, equity-based compensation. Unfortunately, however, managers have been able to use their influence to obtain option plans that appear to deviate substantially from optimal contracting in ways that favor managers.

We wish to emphasize our strong support for equity-based compensation, which in principle can provide managers with very desirable incentives. The devil, however, is in the details. Below we discuss several important features of existing option plans that make option pay less tightly linked to performance than would be beneficial for shareholders: the failure of option plans to filter out windfalls, the almost-uniform use of at-the-money options, and managers' freedom to unload options and shares.

It might be asked why risk-averse managers would not use their influence to get higher cash salaries rather than options. Holding the value of compensation 
constant, one would indeed expect this to happen. But managers seeking to increase their pay during the 1990's did not have a choice between additional compensation in the form of cash and additional compensation in the form of options with the same expected value. Rather, outsiders' enthusiasm about equity-based compensation enabled managers to obtain additional compensation in the form of options without offsetting reduction in cash compensation. Furthermore, the possible benefits from improved incentives provided defensible reasons for very large amount of additional compensation. While Steve Jobs was recently able to obtain an option package worth over half a billion dollars, albeit with some outcry, cash compensation of this order of magnitude is (still) quite inconceivable. The fact that better-designed options could have provided much more cheaply the incentives provided by conventional option plans has not been sufficiently salient to make these plans patently unjustifiable.

\section{B. Option Plans that Fail to Filter Out "Windfalls"}

One widespread and persistent feature of stock option plans is that they fail to filter out stock price rises that are due to industry and general market trends and thus are completely unrelated to managers' own performance. With conventional options, when the market or sector rises substantially, even executives whose companies perform poorly relative to those of their peers can make large profits. Paying managers substantial compensation for stock price increases that have nothing to do with their own performance is difficult to explain under optimal contracting. The substantial amount currently spent on rewarding managers for market or sector rises could either be used to enhance incentives (for example, by giving managers a larger number of options linked more tightly to the managers' relative performance) or be saved with little weakening of incentives.

There are many different ways of designing what we call "reducedwindfall" option plans - plans that filter out all or some of that part of the stock price increase that is unrelated to managers' performance. One approach discussed frequently by academics is linking the exercise price of the options to a market-wide index or a sector index (e.g., Rappaport (1999)). Another strategy is to condition the "vesting" of options on the firm meeting specified performance targets. These targets can be linked to the stock price, earnings per share, or any other measure of firm performance.

When the exercise price of an indexed option is linked to market or sector averages, there is a substantial possibility that the manager will receive no payoff from the option plan. If this possibility were regarded as undesirable, reducedwindfall options could easily be designed to produce a high likelihood of payout. 
For example, the exercise price could be indexed not to changes in the industry or market average but rather to a somewhat lower benchmark - say, the change in the stock price of the firm at the bottom 20th percentile of the industry or market. Under such an option plan, executives would have, on average, an 80 percent probability of outperforming the benchmark and receiving a payout. But executives would not profit, as they could under conventional plans, when their performance places them in the bottom $20^{\text {th }}$ percentile.

Given the wide variety and potential benefits of reduced-windfall options, it is likely that for many firms it would be optimal to filter out at least some of the increase in the stock price that has nothing to do with the managers' own performance. Yet almost all U.S. firms use conventional stock options under which managers capture all of the increase in the stock price. In 2001, only about 5 percent of the 250 largest U.S. public firms used some form of reduced-windfall options (Levinsohn (2001)).

Financial economists have made substantial efforts to develop optimalcontracting explanations for why firms do not use reduced-windfall options. We survey the various explanations in our earlier work (Bebchuk, Fried, and Walker (2002), pp. 803-809) and conclude that none of them can adequately explain the widespread failure to screen out option windfalls. From the perspective of managerial power, however, the failure to filter out general market or industry effects is not at all puzzling. Under this approach, compensation schemes are designed with an eye to benefiting executives while ensuring that the schemes are not perceived as clearly unreasonable. Given that using conventional options is clearly legitimate and acceptable (after all, most firms use them), and that moving to indexing or any other form of reduced-windfall options is likely to be costly or inconvenient for managers, the lack of any real movement toward such options is consistent with the managerial power approach.

\section{At-the-Money Options}

Almost all stock options used to compensate executives are "at-the-money" -- that is, their exercise price is set to the grant-date market price (Murphy (1999), p. 2509). An optimally designed scheme would seek to provide risk-averse managers with cost-effective incentives to exert effort and make valuemaximizing decisions. The optimal exercise price under such a scheme should depend on a multitude of factors that are likely to vary from executive to executive, from company to company, from industry to industry, and from time to time. Such factors might include the degree of managerial risk aversion, which in turn might be affected by the manager's age and wealth, the project choices available to the company, the volatility of the company's stock, the expected rate 
of inflation, and the length of the executive's contract, among other things. There is no reason to expect that "one size fits all" - that the same exercise price level is optimal for all executives at all firms, in all industries, and at all times.

It is therefore highly unlikely that out-of-the-money options - options whose exercise price is above the current market price - are never optimal. Outof-the-money options have a lower expected value than at-the-money options because they are less likely to pay off than at-the-money options, and if they do pay off the holder receives less value. Thus, for every dollar of expected value a firm can give more out-of-the money options than at-the-money options. By giving more out-of-the money options, the firm can increase the reward to the manager for doing particularly well. Out-of-the-money options can thus offer much higher pay-for-performance sensitivity per dollar of expected value than conventional options (Hall (1999)). There is even evidence suggesting that giving managers out-of-the-money options rather than at-the-money-options would, on average, boost firm value (Habib and Ljungqvist (2000)). The almost uniform use of at-the-money options is thus difficult to explain from an optimal contracting perspective. Indeed, economists working within optimal contracting have called this practice a "puzzle" (Hall (1999), p. 43).

The near-uniform use of at-the-money options is not puzzling, however, when examined under the managerial power approach. All else equal, executives prefer a lower exercise price. Because at-the-money options might sometimes be optimal and are employed by almost every other firm, their use in any given case will not generate outrage. Therefore, there is little reason for plan designers to increase the exercise price above the grant-date market price.

Executives would be even better off, of course, if stock options were issued with an exercise price below the grant-date market price. However, such in-themoney options would create a salient windfall and might generate some outrage costs. Furthermore, in-the-money options would trigger a charge to accounting earnings, which might undermine a main excuse for not using indexed options or other reduced-windfall options - that the use of such options would hurt reported earnings. Because in-the-money options might be difficult or costly for plan designers to use, and at-the-money options are the most favorable to managers within the remaining range of possibilities, a uniform use of at-themoney options is consistent with the managerial power approach.

\section{Managers' Freedom to Unwind Equity Incentives}

Another problem for the optimal contracting approach is managers' broad freedom to unload their options and shares. When managers unwind their equity incentives, restoring pay-performance sensitivity requires giving them new 
options or shares. Thus, such unwinding either (1) weakens managers' incentives or (2) forces the firm to give managers new equity incentives to restore incentives to the pre-unwinding level.

Although an executive becomes entitled to options once they have vested, the compensation contract could preclude the executive from "cashing out" the vested options - that is, from exercising the options and then selling the acquired shares - for a specified period after the vesting date. Such a limitation would maintain incentives for an additional period (beyond the vesting date) without requiring the firm to grant new options to replace the ones cashed out.

To be sure, restricting executives' freedom to cash out vested equity instruments imposes on them liquidity and diversification costs that must be balanced against the incentive benefits of restricting unwinding. The efficient arrangement is thus likely to vary from case to case, depending on the executive's and firm's characteristics. But there is no reason to expect that optimal contracts would generally make the vesting date and the cash-out date identical.

Yet, in practice the date on which options vest and the date on which they are exercisable are almost always the same. A minority of firms have created "target ownership plans" that require managers to hold a certain amount of shares, but the targets tend to be rather low, and there often appears to be no penalty imposed for missing the target (Core and Larcker (2002)). As a result of these weak restrictions, managers exercise many of their options well before the options expire, and sell almost all of the shares thereby acquired (Carpenter (1998), Ofek and Yermack (2000)). Shares that are not sold after option exercise are often hedged or partially hedged in transactions that are not reported to the SEC (Bettis, Bizjack, and Lemmon (2001)).

Managers also typically have freedom to determine the precise time of unwinding. Although trading on "material" inside information is illegal, the definition of materiality and the difficulties of enforcement are such that managers making selling decisions can use their superior knowledge about the firm with little fear of liability (Fried (1998)). As a result, managers are able to obtain abnormal returns trading in their firm's shares (Seyhun (1998)). It is far from clear, however, that enabling managers to make such profits is an efficient form of compensation.

Even assuming it is desirable to permit managers to unload shares at a certain stage in their contracts, it does not follow that executives should have absolute control over the exact timing of their sales. After all, liquidity or diversification needs are unlikely to arise unexpectedly one morning. Firms could require that sales be carried out gradually over a specified period, perhaps pursuant to a prearranged plan. Alternatively, firms could require executives to publicly disclose in advance their intended trades, which would reduce their 
ability to profit from informational advantages (Fried (1998)). Yet firms generally do not impose any such restrictions.

Because a firm can be held liable if it fails to take reasonable steps to prevent insider trading by its employees, a number of firms have adopted "trading windows" and "blackout periods" to restrict the times during the year that a manager can sell or buy shares (Bettis, Coles, and Lemmon (2000)). However, many firms have not put such restrictions in place. And even in firms that have imposed such restrictions, managers who know undisclosed bad news at a time they are permitted to trade may use that trading opportunity to unwind a substantial amount of their holdings. Thus, executives retain considerable ability to dump shares before bad news becomes public. In one notorious case, Enron insiders sold hundreds of millions of shares before information about Enron's actual financial condition was released and the stock price collapsed.

Although managers' ability to unwind equity incentives early and to control the time of such unwinding cannot easily be explained under optimal contracting, it is quite consistent with the managerial power approach. Broad freedom to unload equity instruments provides managers with substantial benefits that are not particularly conspicuous. The corresponding costs to shareholders from diluted incentives are also not salient. Furthermore, and perhaps most importantly, managers' unwinding of options and shares provides a convenient justification for frequently granting managers new equity-based incentives, thereby boosting their total compensation. Although a system of constant unwinding and replenishing incentives is more costly to shareholders than one that requires managers to hold options and shares for longer periods, it is obviously much better for managers.

\section{E. The "Perceived Cost" Explanation}

Murphy (2002) and Hall and Murphy (2003) put forward a "perceived cost" explanation for the use of conventional, at-the-money options. According to their explanation, executives and directors erroneously perceive conventional options to be "cheap" or even "nearly free to grant" because such options can be granted without any cash outlay and without reducing reported earnings.

We doubt that executives and their advisers do not grasp the costs of conventional options to shareholders. Assuming that Hall and Murphy are correct in suggesting that managers believe that the stock market is influenced by accounting numbers rather than underlying economic reality, this would at most mean that executives believe that investors under-estimate or ignore the costs of options that are not expensed for accounting purposes - not that executives 
themselves fail to see the significant economic costs that conventional options impose on shareholders (whose ownership interest the options dilute).

One might even be skeptical that directors, many of whom are business executives themselves, overlook the costs of options to shareholders. Indeed, if directors had so little financial sophistication, then the corporate governance model based on board monitoring is in even worse shape than our analysis suggests. Let us suppose, however, that directors have been oblivious to the true cost of conventional options. If so, such a misperception on the part of directors is best seen not as an alternative to the managerial power explanation but rather as one of the factors contributing to managers' ability to exert considerable influence over the terms of their pay.

As we discussed earlier, there are several reasons why boards cannot be expected to engage in arms' length negotiations with the CEO over executive compensation, and one of them is directors' lack of adequate time and easy access to accurate, unbiased information. To the extent directors in fact did misperceive the cost of options, such misperceptions would simply be part of the informational problem that contributes to directors' willingness to approve suboptimal arrangements. If directors were ignorant about such important and widely discussed issues as the actual cost of options, they would likely be inadequately informed, and thus ineffectively monitor, other features of compensation arrangements.

In our view, inadequate information is just one of the factors, alongside inadequate incentives and others, that might lead directors to agree to pay arrangements that favor managers. For one thing, directors' confusion over the cost of options cannot explain the systematic relationship between power and pay, and managers' efforts to make compensation less salient using executive loans and retirement benefits. For many purposes, however, it does not matter whether directors' willingness to accept arrangements that favor executives is the result of conscious favoritism, honest misperceptions, inadequate incentives to exert effort, or some combination of these factors. The important thing is that directors do not adequately represent shareholders' interests in bargaining with managers over their pay, and that pay arrangements consequently depart from the arm's length model in directions favorable to executives.

\section{COSTS TO SHAREHOLDERS}

What are the costs imposed on shareholders by managers' influence over their own pay? To begin with, there is the excess pay managers receive as a result of their power - the difference between what managers' influence enables them to obtain and what they would obtain under an arm's length arrangement. Some 
might think that this problem is only symbolic, and that these rents have little actual effect on shareholders' bottom line. But a close look at the amounts involved indicates that they add up to much more than small change (Bebchuk and Cohen (2003)). In 2000, CEO compensation in the firms making up the 1500company ExecuComp dataset was on average $7.89 \%$ of corporate profits (Balsam (2002), p. 262).

Furthermore, and perhaps more importantly, managers' ability to influence their pay leads to compensation arrangements that generate worse incentives than those that arm's length contracts would provide. Managers have an interest in compensation schemes that camouflage the extent of their rent extraction or that put less pressure on them to reduce slack. As a result, managerial influence might lead to the adoption of compensation arrangements that provide weak or even perverse incentives. In our view, the reduction in shareholder value caused by these inefficiencies, rather than the excess rent captured by managers, could be the largest cost arising from managers' ability to influence their compensation.

First of all, compensation arrangements currently provide weaker incentives to reduce managerial slack and increase shareholder value than likely would be provided by arm's length arrangements. As explained, both the nonequity and equity components of managers' compensation are substantially more decoupled from the managers' contribution to firm performance than appearances might suggest. Shareholders thus might benefit substantially from the improved performance that a move toward optimal contracting arrangements could generate.

Prevailing practices not only fail to provide cost-effective incentives to reduce slack but also create perverse incentives. For one thing, they provide managers' incentives to change firm parameters in a way that would justify increases in pay. Consider, for example, the familiar problem of empire-building. It is commonly believed that the practice of granting options provides managers with incentives not to undertake acquisitions that are value-decreasing for shareholders. This is clearly the case, however, only in a static model in which all option grants are made before managers make acquisition decisions. In a dynamic model, managers considering an expansion decision that is somewhat valuedecreasing for shareholders would have different incentives: While such an expansion would reduce the value of their current options, it may well raise their aggregate future compensation by an even greater amount because a larger firm size can be used to justify higher pay.

Furthermore, managers' broad freedom to unload equity incentives can produce substantial inefficiencies. Executives who expect to unload their shares or options have a weaker incentive to exert ex ante efforts whose payoffs are not going to be recognized by the market at the time they unwind their equity 
positions (Bar-Gill and Bebchuk, 2003a). Such executives also have incentives to misreport corporate performance and suppress bad news (Bar-Gill and Bebchuk, 2002). Indeed, such executives also have incentives to choose projects that are less transparent or to reduce the transparency of existing projects (Bar-Gill and Bebchuk, 2003b). The efficiency costs of such distortions might exceed, possibly by a large amount, whatever liquidity or risk-bearing benefits executives obtain from being able to unload at will their options and shares.

\section{CONCLUSION}

There are good theoretical and empirical reasons for concluding that managerial power substantially affects the design of executive compensation in companies marked by a separation of ownership and control. Executive compensation can thus be fruitfully analyzed not only as an instrument for addressing the agency problem arising from the separation of ownership and control -- but also as part of the agency problem itself.

The conclusion that managerial power and rent extraction play an important role in executive compensation has significant implications for corporate governance, which we explore in our forthcoming book (Bebchuk and Fried, 2004). It is important to note, however, that this is an area in which widespread recognition of the problem might contribute to alleviating it. The extent to which managerial influence can move compensation arrangements away from optimal contracting outcomes depends on the extent to which market participants, especially institutional investors, recognize and are on guard against, the problems we have discussed. Financial economists can thus make an important contribution to improving compensation arrangements by analyzing how compensation practices deviate from those suggested by optimal contracting. We hope that future studies of executive compensation will devote to the role of managerial power as much attention as the optimal contracting model has received. 


\section{References}

Abelson, Reid. 2001. "Enron Board Comes Under a Storm of Criticism." N.Y. Times, December 16, C4.

Agrawal, Anup and Charles R. Knoeber. 1998. "Managerial Compensation and the Threat of Takeover." Journal of Financial Economics 47:2, pp. 219-239.

Baker, George P., Michael C. Jensen, and Kevin J. Murphy. 1988. "Compensation and Incentives: Practice vs. Theory." Journal of Finance 63:3, pp. 593-616.

Balsam, Steven. 2002. An Introduction to Executive Compensation (Academic Press). Bar-Gill, Oren and Lucian Bebchuk. 2002. "Misreporting Corporate Performance." Working Paper No. 400, Harvard Olin Center for Law, Economics, and Business, available at <http://www.ssrn.papers/abstact $=354141>$.

Bar-Gill, Oren and Lucian Bebchuk. 2003a. "The Costs of Permitting Managers to Sell Shares." Mimeo, Harvard Law School.

Bar-Gill, Oren and Lucian Bebchuk. 2003b. "Corporate Transparency and Managerial Incentives." Mimeo, Harvard Law School.

Bebchuk, Lucian, John Coates IV and Guhan Subramanian. 2002. "The Powerful Antitakeover Force of Staggered Boards: Theory, Evidence, and Policy." Stanford Law Review 54, pp. 887-951.

Bebchuk, Lucian, and Alma Cohen. 2003. "The Costs of Executive Compensation," mimeo, Harvard Law School and NBER.

Bebchuk, Lucian Arye and Jesse M. Fried. 2004. Pay without Performance: The Unfulfilled Promise of Executive Compensation (forthcoming, MIT Press).

Bebchuk, Lucian Arye and Jesse M. Fried. 2003. "Stealth Compensation." mimeo, Harvard Law School and Boalt Hall School of Law.

Bebchuk, Lucian Arye, Jesse M. Fried, and David I. Walker. 2002. "Managerial Power and Rent Extraction in the Design of Executive Compensation." University of Chicago Law Review 69:3, pp. 751-846.

Bebchuk, Lucian Arye, and Marcel Kahan. 1990. “A Framework for Analyzing Legal Policy Toward Proxy Contests." California Law Review 78, 1071-1136.

Benz, Matthias, Marcel Kucher, and Alois Stutzer. 2001. “Stock Options: The Managers' Blessing: Institutional Restrictions and Executive Compensation." Working Paper No. 61, University of Zurich Institute for Empirical Research in Economics.

Berle, Adolf A., Jr. and Gardiner C. Means. 1932. "The Modern Corporation and Private Property." (The Macmillan Company, New York).

Bertrand, Marianne and Sendhil Mullainathan. 2001. "Are CEO's Rewarded for Luck? The Ones Without Principals Are." Quarterly Journal of Economics, pp. 901-932. 
Bettis, J. Carr, John M. Bizjak, and Michael L. Lemmon. 2001. “Managerial Ownership, Incentive Contracting, and the Use of Zero-Cost Collars and Equity Swaps by Corporate Insiders." Journal of Financial and Quantitative Analysis 36, pp. 345-70.

Bettis, J. Carr, Jeffrey L. Coles, and Michael L. Lemmon. 2000. “Corporate Policies Restricting Trading by Insiders." Journal of Financial Economics 57, pp. 191$\mathrm{xxx}$.

Bizjack, John M., Michael L. Lemmon, and Lalitha Naveen. 2000. "Has the Use of Peer Groups Contributed to Higher Levels of Executive Compensation?" Working Paper, Portland State University.

Blanchard, Olivier Jean, Florencio Lopez-de-Silanes, and Andrei Shleifer. 1994. "What do Firms do with Cash Windfalls?" Journal of Financial Economics. 36, pp. 337-360.

Borokhovich, Kenneth A., Kelly R. Brunarski, and Robert Parrino. 1997. "CEO Contracting and Anti-Takeover Amendments." Journal of Finance 52:4, pp. 1495-1517.

Carpenter, Jennifer N. 1998. "The Exercise and Valuation of Executive Stock Options." Journal of Financial Economics 48, pp. 127-158.

Cheng, Shjun, Venky Nagar, and Madhar V. Rajan. 2001. "Control Versus Risk in Stock-Based Incentives: Evidence from Antitakeover Regulation." Working Paper, University of Michigan Business School.

Core, John E., Robert W. Holthausen, and David E. Larcker. 1999. "Corporate Governance, Chief Executive Compensation, and Firm Performance." Journal of Financial Economics 51, pp. 371-406.

Core, John E., Wayne Guay, and David F. Larcker. 2001. “Executive Equity Compensation and Incentives: A Survey," Working Paper, Wharton School.

Core, John E. and David Larcker 2002, "Performance Consequences of Mandatory Increases in Executive Stock Ownership." Working paper, Wharton School.

Crystal, Graef S. 1991. In Search of Excess. Norton.

Cyert, Richard, Sok-Hyon Kang, and Praveen Kumar. 2002. "Corporate Governance, Takeovers, and Top-Management Compensation: Theory and Evidence." Management Science 48:4, pp. 453-469.

David, Parthiban, Rahul Kochar, and Edward Levitas. 1998. "The Effect of Institutional Investors on the Level and Mix of CEO Compensation." Academy of Management Journal 41:2, pp. 200-208.

Fox, Justin. 2001. "The Amazing Stock Option Sleight of Hand." Fortune June 25, pp. 86-92. 
Fried, Jesse M. 1998. "Reducing the Profitability of Corporate Insider Trading through Pre-trading Disclosure." Southern California Law Review 71:2, pp. 303-392.

Gillan, Stuart. 2001. "Has Pay for Performance Gone Awry: Views from a Corporate Governance Forum." Research Dialogue. TIAA CREF Institute. 68, pp. 1-16.

Habib, Michel A. and Alexander P. Ljungqvist. 2000. "Firm Value and Managerial Incentives." Working Paper, London Business School.

Hall, Brian J. 1999. "A Better Way to Pay CEO's?" in Executive Compensation and Shareholder Value: Theory and Evidence. Jennifer Carpenter and David Yermack, eds. Kluwer Academic, pp. 35-46.

Hall, Brian J. and Kevin J. Murphy. 2000. "Optimal Exercise Prices for Executive Stock Options." American Economic Association Proceedings 90, pp. 209-214.

Hall, Brian J. and Kevin J. Murphy. 2003. "The Trouble with Stock Options." Journal of Economic Perspectives (this issue).

Hallock, Kevin. 1997. "Reciprocally Interlocking Boards of Directors and Executive Compensation." Journal of Financial and Quantitative Analysis 32:3, pp. 331-334.

Hartzell, Jay C. and Laura T. Starks. 2002. "Institutional Investors and Executive Compensation." Working Paper, New York University Stern School of Business.

Jensen, Michael 1986. "Agency Costs of Free Cash Flow, Corporate Finance, and Takeovers." American Economic Review 76, pp. 323-329.

Jensen, Michael, and William Meckling. 1976. "Theory of the Firm: Managerial Behavior, Agency Costs, and Ownership Structure." Journal of Financial Economics 3, pp. 305-360.

Jensen, Michael, and Kevin Murphy. 1990. "Performance Pay and Top Management Incentives." Journal of Political Economy 98, pp. 225-263.

Johnson, Marilyn F., Susan Porter, and Margaret B. Shackell. 1997. "Stakeholder Pressure and the Structure of Executive Compensation." Working Paper, Michigan State University, University of Massachusetts at Amherst, Notre Dame.

King, Ralph. 2002. “Insider Loans: Everyone Was Doing It." Business 2.0. November.

Leonhardt, David. 2002. "It's Called a Loan, But It's Far Sweeter." New York Times, February 3, Section 3, Page 1.

Levinsohn, Alan. 2001. "A Garden of Stock Options Helps Harvest Talent." Strategic Finance 82, pp. 81-82. 
Lublin, Joan. 2002. "As their Companies Crumbled, some CEO's Got Big-money Payouts." Wall Street Journal, Feb 26, p. B1.

Murphy, Kevin J. 1999. "Executive Compensation." in Handbook of Labor Economics. Orley Ashenfelter and David Card, eds. North Holland, pp. 2485-2563.

Murphy, Kevin J. 2002. "Explaining Executive Compensation: Managerial Power vs. the Perceived Cost of Stock Options." University of Chicago Law Review 69 , pp. 847-869.

Pearl Meyers \& Partners. 2002. Executive Pay Trends: Looking Forward and Looking Back.

Ofek, Eli and David Yermack. 2000. "Taking Stock: Equity-Based Compensation and the Evolution of Managerial Ownership." Journal of Finance 55:3, pp. 1367-1384.

Rappaport, Alfred. 1999. “New Thinking on How to Link Executive Pay with Performance." Harvard Business Review March-April, pp. 91-101.

Seyhun, H. Nejat. 1998. Investment Intelligence from Insider Trading, MIT Press.

Shleifer, Andrei and Robert W. Vishny. 1986 . "Large Shareholders and Corporate Control." Journal of Political Economy 94:3, pp. 461-88.

Shleifer, Andrei, and Robert Vishny. 1989. "Management Entrenchment: The Case of Manager-specific Investments." Journal of Financial Economics 25, pp. 123140.

Shleifer, Andrei, and Robert Vishny. 1997. "A Survey of Corporate Governance." Journal of Finance 52, pp. 737-783.

Thomas, Randall S. and Kenneth J. Martin. 1999. "The Effect of Shareholder Proposals on Executive Compensation." University of Cincinnati Law Review 67, pp. 1021-1081.

Wade, James B., Joseph Porac, and Timothy Pollock. 1997. "Worth, Words, and the Justification of Executive Pay." Journal of Organizational Behavior 18, pp. 641-664.

Williamson, Oliver, 1964. The Economics of Discretionary Behavior: Managerial Objectives in a Theory of the Firm (Prentice Hall, Englewood Cliffs, N.J.).

Yermack, David. 1997. "Good Timing: CEO Stock Option Awards and Company News Announcements." Journal of Finance 52, pp. 449-476. 